\title{
On Turkey's trade policy: Is a customs union with Europe enough?
}

\author{
Jean Mercenier ${ }^{a}$, Erinç Yeldan ${ }^{b, *}$ \\ ${ }^{a}$ C.R.D.E. and Département de sciences économiques, Université de Montréal, Montréal, Canada \\ ${ }^{\mathrm{b}}$ Department of Economics, Bilkent University, 06533 Ankara, Turkey
}

\begin{abstract}
Turkey has decided to harmonize its tarification structure with that of the European Union. For the country's authorities, this move to a Customs Union is only meant to be the first step toward integration in the European Union. There are signs, however, that political opposition to the government's procompetitive stance may be strong enough to block any further move toward fuller trade liberalization. We show, using applied intertemporal GE analysis, that to be welfare improving, the trade reform would have to be pursued further and nontariff barriers on European trade removed. Failure to do so could be more detrimental to domestic welfare than no reform at all. (C) 1997 Elsevier Science B.V.
\end{abstract}

JEL classification: C68; D58; F12; F13; F15; F17; O52

Keywords: Dynamic applied general equilibrium; Imperfect competition; Turkey; Customs union

\section{Introduction}

Turkey (TR) has long held aspirations of becoming a full member of the former European Economic Community (EEC), now the European Union (EU). Despite the rejection of its official re-application for full membership in April 1987, TR

\footnotetext{
" Corresponding author. Tel.: (+90) 312- 266.4040/1659; fax: (+90) 312-266.4960; e-mail: yeldane@bilkent.edu.tr
} 
pursued unilaterally its trade liberalization efforts vis-à-vis the EEC by substantially reducing its sectoral tariffs on its European imports. In March 1995, TR decided to harmonize its tariffication structure with that of the EU in a 'Customs Union' (CU) which has been put into effect in January, 1996.

For the Turkish authorities today, this move to a CU is only meant to be the first step toward the country's integration in the EU. The next phase will require complying with the European Single Market rules, i.e., full integration of the commodity markets. ${ }^{1}$ As one expects, such a pro-competitive policy does not gencrate unanimous support in the country. Lobby groups arc actively working to mobilize various elements of opposition to bring the pro-competitive effort to a stop. The outcome of this political game is of course hard to predict, but it seems unlikely that the opposition parties will manage to force a complete policy reversal in the immediate future. Hence, a likely compromise could be as follows: the CU is history in the making and therefore a fact, but achievement of the second phase of the trade reform program has to be postponed if not altogether dropped from the agenda.

It is our objective in this paper to shed some light on the desirability, for TR, of such a status quo. For this purpose, we use an applied intertemporal general equilibrium (GE) model of trade and production which recognizes increasing returns to scale technologies in some sectors, existence of firm level product differentiation, and oligopolistic market structures. ${ }^{2}$ Our findings suggest strong negative welfare effects from the $\mathrm{CU}$ with Europe, because of the initially heavily distorted nature of the Turkish economy. In contrast, the second phase of the trade reform is projected to yield substantial gains for the domestic economy, though the cumulative gains remain rather modest. Our conclusion is therefore clear: from the point of view of TR, simple harmonization of the tariff system - the CU - can only be regarded as an interim phase which has to be complemented with further steps toward full market integration with the EU. A political compromise that would result in a CU status quo appears to be the worst possible option with likely negative welfare consequences for the country.

The plan of the paper is as follows. Section 2 introduces the main features of our GE model, and makes precise our measure of welfare. The policy scenarios are presented in Section 3 together with a discussion of the main mechanisms at work based on partial equilibrium arguments. In Section 4, we discuss the policy results, and we conclude in Section 5.

\footnotetext{
${ }^{1}$ Ultimately, monetary and labor market integration will have to be achieved if TR is to become a full member of the EU. This third phase will not be achieved in the near future for both economical and political reasons. We therefore disregard this policy option.

${ }^{2}$ Previous applied GE analyses of the Turkish economy are static: e.g., Celasun (1986), Yeldan (1989), Harrison et al. (1993).
} 


\section{The model ${ }^{3}$}

Turkey (TR) is part of a world economy consisting of itself and six other regions (Great Britain, Germany, France, Italy, the rest of the EU, and the rest of the world.) Each country has nine sectors of production, of which four are perfectly competitive. ${ }^{4}$ In these sectors, countries are linked by an Armington system so that commodities are differentiated in demand by their geographical origin. The other five industries are modeled as noncompetitive. ${ }^{5}$ In the latter sectors, firms are assumed to be symmetric within national boundaries. They operate with fixed primary factor costs and therefore face increasing returns to scale in production. They have no monopsony power. Each individual oligopolist produces a different good. Industry structure is assumed fixed in the short run; oligopolistic firms may then experience non-zero profits. In the long run, however, entry and exit of competitors in a Chamberlinian fashion ensure that these rents vanish. The competitive game between oligopolistic firms is assumed to be static Cournot-Nash. The instantaneous GE concept adopted is a compromise in terms of informational requirements between the primitive conjectural Cournot-NashWalras equilibrium of Negishi and the objective Cournot-Nash-Walras equilibrium introduced by Gabszewicz and Vial. ${ }^{6}$ In all sectors, competitive and noncompetitive, a detailed country- and sector-specific system of price-responsive intermediate demands is specified that recognizes differences among products from individual oligopolistic suppliers à la Ethier.

Final demand decisions are made in each country by a single representative household that is competitive, infinitely lived, and utility-maximizing. The domestic household owns all the country's primary factors, namely, labor and physical capital, which it rents to domestic firms only, at the same competitive price regardless of the sector. ${ }^{7}$ In the short run, however, total returns to capital may differ across industries: oligopolistic profits may add to capital rental earnings because of unexpected shocks. We abstract from leisure/labor decisions and population growth so that the variables under household control are consumption

\footnotetext{
${ }^{3}$ The data are discussed in Mercenier (1995a), Mercenier and Yeldan (1996) and Kose and Yeldan (1996). Sce Mcrcenicr and Ycldan (1996) for a formal description of the model, of the calibration and solution procedures.

${ }^{4}$ The four perfectly competitive sectors are agriculture and primary products; food, beverage, and tobacco; other manufacturing industries (textile, wood, paper, metallurgy and minerals); and transport and services.

${ }^{5}$ The noncompetitive industries are pharmaceutical products; chemistry other than pharmaceutical products; motor vehicles; office machinery; and other machinery and transport materials.

${ }^{6}$ Noncompetitive firms neglect the feedback effect of their decisions on their profits via income (the Ford effect) and via input-output multipliers (the Nikaido effect).

${ }^{7}$ The risk of multiple equilibria highlighted by Mercenier (1995b) is reduced by the assumption that physical factors are internationally immobile.
} 
and investment. In making optimal decisions subject to their intertemporal budget constraints, households can borrow or lend on international markets. All final demands recognize differences among products from individual oligopolistic firms à la Dixit and Stiglitz.

The only explicit role of the government is to raise tariffs, the proceeds of which are rebated to domestic consumers lump-sum. National markets are assumed to be segmented in the initial equilibrium: because of nontariff barriers (NTBs) that prevent customers from cross-border arbitraging, noncompetitive firms behave as price-discriminating oligopolists.

The model is calibrated on base year data assuming the world economy in steady state. For the computation of the transitional dynamics, we make use of recent results by Mercenier and Michel (1994) on temporal aggregation: the model is solved on a horizon of 35 years using five unequally distant grid dates: $t_{0}=1$, $t_{1}=5, t_{2}=10, t_{3}=20$, and $t_{4}=35$.

Central to our analysis is the measure of welfare gains. Let $\hat{C}(t)$ be the reference stream of consumption and $C(t)$ be the corresponding time profile computed after implementation at $t=0$ of a once and for all previously unexpected trade policy change. The welfare gain is determined from the following utility indifference condition:

$$
\int_{0}^{\infty} \mathrm{e}^{-\rho t}[\hat{C}(t)(1+\phi)]^{1-\gamma} \mathrm{d} t=\int_{0}^{\infty} \mathrm{e}^{-\rho t} C(t)^{1-\gamma} \mathrm{d} t,
$$

that is, the welfare gain resulting from the policy change is equivalent from the perspective of the representative Turkish household to increasing the reference consumption profile by $\phi$ percent.

\section{Description of the experiments}

\subsection{The benchmark}

Nominally at least, the European Single Market has been completed since January 1993. In practice, of course, the program will take some time to become fully implemented and indeed longer still before its effects can be observed in the data. We therefore generate as an initial simulation the new international environment in which Turkey has to make its future policy decisions, i.e., we compute the post-Europe ' 92 equilibrium. This equilibrium serves as the benchmark for our following policy simulations.

\subsection{The trade policy experiments}

In our first experiment, we implement the Turkish commitment to enter a CU with the EU. Technically, this consists to set most tariffs on European imports to 
zero and to harmonize most rates on imports from the ROW with the existing European rates.

In the second experiment, TR is assumed to join the European Single Market. (See, among others, Smith and Venables, 1988, and Mercenier, 1995a.) This implies that, in addition to tariff harmonization, both the Turkish and the European firms switch from their initial price-discriminating strategy to a single-pricing behavior within the Extended $E U$ (henceforth: $\mathrm{EEU}=\mathrm{EU}+\mathrm{TR}$ ). Formally, let $v_{i, s}$ be the marginal production cost of a firm operating in sector $s$ of country $i$; $z_{i, s, j}$ and $p_{i, s, j}$ respectively the amount sold and the price charged by the same firm on market $j$. The optimal pricing strategy of the firm is determined from

$$
\frac{p_{i, s, \mathrm{TR}}-v_{i, s}}{p_{i, s, \mathrm{TR}}}=\lambda \frac{\partial \log p_{i, s, \mathrm{TR}}}{\partial \log z_{i, s, \mathrm{TR}}}+(1-\lambda) \frac{\partial \log p_{i, s, \mathrm{EEU}}}{\partial \log z_{i, s, \mathrm{EEU}}}
$$

with $\lambda=1$ in the calibration. The experiment consists to set $\lambda=0$ with the elasticity on the right is evaluated using the EEU-aggregated demand. The rationale behind this experiment is as follows. NTBs confer to firms (domestic and foreign) the power to price discriminate between TR and other markets. Full integration of TR in the EU involves suppressing all forms of NTBs. This should restore cross-border arbitraging and force firms to charge a unique price within the EEU. Because NTBs are essentially unobservable, we treat them as latent variables, and generate the effects of their elimination by forcing the individual firms to adopt single pricing within the (now extended) European market on the basis of their average EFU-wide monopoly power.

What can TR expect from such a trade integration experiment in terms of welfare? Turkish firms are thought, initially, to charge higher prices in their domestic market, in which they usually hold the largest share. A move to a single-price strategy within the EEU would, therefore, induce a reduction of prices charged by those firms on the home market (see Table 1 for the calibrated price spread for chemicals). The conjecture is that consumer prices will decline relative to factor prices and that Turkish households will be better off. In addition, in the long run, a rationalization effect à la Harris could result from adjustments in industry structure. Indeed, the new pricing rule could reduce industry profits, induce exit so that a smaller number of surviving firms would operate on a larger scale with lower average costs. The positive outcome for the consumer of this structural adjustment could, however, be offset by two companion effects. Exit of firms from an industry reduces product diversity which has a direct welfare cost, since consumers love variety (the Dixit and Stiglitz specification). Furthermore, diversity in available intermediate goods affects production efficiency in all sectors: everything else equal, exit of firms in an industry increases variable unit costs in all other sectors, competitive and noncompetitive (the Ethier specification). Our aim here is to measure these effects and analyze how they combine to affect the level and pattern - intertemporal and intersectoral - of welfare, production, and employment. 
Table 1

Selected results for the Turkish chemicals industry

\begin{tabular}{|c|c|c|c|}
\hline \multirow[t]{8}{*}{ Calibrated spread of prices to: } & & GB & 0.869 \\
\hline & & $\mathrm{D}$ & 0.869 \\
\hline & & $\mathrm{F}$ & 0.869 \\
\hline & & I & 0.869 \\
\hline & & Rest of EU & 0.869 \\
\hline & & TR & 1.010 \\
\hline & & RoW & 0.869 \\
\hline & & On impact (first year) & On steady state \\
\hline \multicolumn{4}{|c|}{ Effects of customs union with EU (\% changes w.r.to base case) } \\
\hline Average selling price & $\bar{p}$ & -12.7 & -11.1 \\
\hline Variable unit cost & $v$ & -10.3 & -10.5 \\
\hline Wage rate & $w$ & -7.7 & -9.0 \\
\hline Rental price of capital & $r$ & -7.7 & -11.2 \\
\hline Average cost & $V$ & -8.1 & -11.1 \\
\hline Output scale (per firm) & $Q$ & -4.6 & 1.8 \\
\hline Number of firms & $n$ & 0.0 & -28.7 \\
\hline Efficiency gains & & -4.4 & 2.0 \\
\hline \multicolumn{4}{|c|}{ Full commodity market integration with EU (\% changes w.r. to post customs union equilibrium } \\
\hline Average selling price & $\bar{p}$ & -4.8 & -6.5 \\
\hline Variable unit cost & $v$ & 0.1 & -0.6 \\
\hline Wage rate & $w$ & 2.2 & 1.9 \\
\hline Rental price of capital & $r$ & 2.5 & 0.4 \\
\hline Average cost & $V$ & -3.8 & -6.5 \\
\hline Output scale (per firm) & $Q$ & 17.4 & 30.8 \\
\hline Number of firms & $n$ & 0.0 & -0.9 \\
\hline Efficiency gains & & 14.7 & 25.1 \\
\hline
\end{tabular}

\subsection{Highlight of the basic mechanisms at work}

Systematic sectoral patterns are, of course, not to be expected because of GE effects. One may nevertheless trace the type of adjustments that take place using selected sectoral variables and partial equilibrium arguments. For this purpose, we give in Table 1 some results for TR's chemical industry. The first part of the table illustrates the importance of market segmentation in the calibrated equilibrium: Turkish firms in this industry clearly charge higher prices on the domestic market.

The second part of the table reports on the effects of TR's forming a CU with the EU. Numbers are percentage deviations from the benchmark. For clarity, we only report results for the first year following the policy implementation and for the steady state. As Turkish customers substitute in favor of foreign goods, domestic prices are forced downward in all sectors which induces a fall in factor prices ( $w$ and $r$ ). Variable unit costs $v$ therefore unambiguously fall in all sectors, as well as total fixed costs in those industries that are noncompetitive. In the 
domestic market, foreign penetration erodes the monopoly power previously enjoyed by local producers in the chemical industry: the firm's average selling price $\bar{p}$ falls by $12.7 \%$. Note that in this industry, the drop in $\bar{p}$ unambiguously exceeds the cost saving effect of the trade liberalization (average costs $V$ decline by $8.1 \%$ ) so that, even if the production scale were to remain unchanged, the firm would experience negative profits. The situation is actually worse: because of a combination of substitution and income effects, the firm is forced up along its average cost curve since the volume of its sales $Q$ declines by $4.6 \%$. The average scale in the Turkish chemical industry is unambiguously too small for all existing firms to survive. More than a quarter of the firms will be forced out of the market $(28.7 \%)$, hence making it possible for survivors to operate more efficiently, i.e., on a larger scale $(1.8 \%)$ with lower total unit costs $(11.1 \%)$. The long-term efficiency gains (i.e., the real cost savings due to increased scale on initial output) achieved in the sector because of this industry-rationalization mechanism amounts to approximately $2.0 \%$.

In the third part of Table 1 , we report on the effects of TR's joining the European Single Market. All numbers are percentage deviations from the post-CU equilibrium. The adoption of the single-price rule within the EEU results in lower prices for domestic consumers and lower average selling prices for local producers of chemical products in the short run $(-4.8 \%)$. This boosts demand up by $17.4 \%$. At the aggregate level, the same mechanism operates resulting in increased competition for resources (short-term wages and capital rentals increase by approximately $2 \%$ ) but generally with lower prices in noncompetitive industries. As a result, the variable unit costs in Turkish chemicals are essentially unchanged $(+0.1 \%)$. Though total fixed costs have also increased, unit production costs have been reduced by $3.8 \%$ since the firms now operate at larger scale. The achieved gains in efficiency $(14.7 \%)$ are, however, not large enough to prevent existing firms from experiencing negative profits and some producers will be forced out of that industry. The necessary long-term change in industry concentration turns uut to be quite modest $(-0.9 \%)$ thanks to growth effects which will be documented in the next section.

\section{Is a customs union with Europe enough?}

We now turn to GE effects and concentrate our attention on major aggregate variables. In all calculations, we use a discount rate of $7 \%$. The first part of Table 2 reports the computed effects of the $\mathrm{CU}$ currently under implementation. The tariff reform induces a strong deterioration of the terms of trade. The wealth contraction shifts the time profile of consumption downward. Investment increases over the whole time horizon, however, despite the negative wealth shock. This is because the new time structure of prices make it optimal for consumers to substitute future for current consumption. Hence, production capacities increase though not monotonously: the capital stock overshoots its new steady-state level 
Table 2

Dynamic GE effects of trade liberalization scenarios for Turkey

\begin{tabular}{|c|c|c|c|c|c|}
\hline Years & 1 & 5 & 10 & 20 & 35 \\
\hline \multicolumn{6}{|c|}{ a: Customs union with EU (\% changes from benchmarch) (Welfare $(\phi)=-0.832)$} \\
\hline Consumption & -1.82 & -1.12 & -0.53 & -0.27 & -0.34 \\
\hline Investment & 6.42 & 4.57 & 1.67 & 0.30 & 0.90 \\
\hline Capital & 0.00 & 1.32 & 1.99 & 1.86 & 0.90 \\
\hline Efficiency gains & -4.95 & -2.78 & -1.12 & 0.71 & 2.88 \\
\hline Wage rate & -7.71 & -7.82 & -8.16 & -8.53 & -8.98 \\
\hline Rental price of capital & -7.74 & -9.30 & -10.40 & -11.04 & -11.24 \\
\hline \multicolumn{6}{|l|}{ Price indexes of: } \\
\hline - consumption & -9.35 & -10.00 & -10.52 & -10.75 & -10.68 \\
\hline - investment & -10.06 & -10.63 & -11.08 & -11.26 & -11.21 \\
\hline Terms of trade & -9.02 & -9.69 & -10.21 & -10.48 & -10.49 \\
\hline \multicolumn{6}{|c|}{$\begin{array}{l}\text { b: Full commodity market integration with EU (\% Changes from customs union) } \\
\text { (Welfare }(\phi)=+0.897)\end{array}$} \\
\hline Consumption & 0.28 & 0.69 & 1.05 & 1.23 & 1.28 \\
\hline Investment & 4.50 & 3.79 & 2.33 & 1.92 & 1.89 \\
\hline Capital & 0.00 & 0.92 & 1.51 & 1.85 & 1.89 \\
\hline Efficiency gains & 12.36 & 13.22 & 14.03 & 15.55 & 18.40 \\
\hline Wage rate & 2.25 & 2.25 & 2.14 & 2.05 & 1.94 \\
\hline Rental price of capital & 2.52 & 1.63 & 0.97 & 0.58 & 0.39 \\
\hline \multicolumn{6}{|l|}{ Price indexes of: } \\
\hline - consumption & 1.24 & 0.85 & 0.53 & 0.36 & 0.32 \\
\hline - investment & 1.17 & 0.84 & 0.54 & 0.40 & 0.37 \\
\hline Terms of trade & 1.38 & 1.02 & 0.72 & 0.57 & 0.56 \\
\hline
\end{tabular}

during the transition. As a result, the long-term supply of capital services only mildly increases, by less than $1 \%$. Important intersectoral adjustments take place simultaneously. In particular, rationalization of imperfectly competitive industries improve the competitiveness of the country's industrial sector, generating long-term aggregate efficiency gains (i.e., real cost savings due to increased scale on initial output) of almost $3 \%$. However, the policy's overall positive impact on steady-state factor supply and efficiency is too modest to compensate for the terms of trade loss: the welfare cost amounts to a sacrifice of real consumption on the whole time horizon of almost $1 \%(\phi=-0.832 \%)$. The results clearly suggest that a partial trade liberalization policy, limited to the tariff harmonization reform as currently under implementation, is undesirable.

If Turkey were to join the European Single Market, it would have to get rid not only of tariffs but also of all forms of NTBs. The elimination of NTBs shifts up the time path of consumption, but only mildly affects the time profile of aggregate variables. The second part of Table 2 confirms that the overall impact on the economy is quite substantial. The reason is to be found in sectors of activity initially dominated by inefficient local oligopolists. The opening up of domestic 
markets to international competition forces Turkish producers to cut prices in the domestic market and to move down along their average cost curve to face the induced expansion of demand. The efficiency gains hence achieved by the second-phase reform vary between 12 and 19\% (depending on the position on the time axis). The cost-saving shock has a positive wealth effect which is responsible for the upward shift of the consumption profile. It also boosts up capital accumulation with an expansion of steady-state capacities close to $2 \%$. Domestic consumers are clearly made better-off under this extended policy reform: real consumption has unambiguously increased on the whole time horizon. More formally, to be indifferent between this and the previous equilibrium allocations, Turkish households would have to be compensated in the latter case by an amount equivalent to almost one percent of their consumption flows over the whole time horizon $(\phi=+0.897 \%)$. Observe from the cumulated equivalent variation, that the welfare effect for TR of full trade integration with the EU is positive.

What we learn from these numbers is plain: a partial trade reform in the form of a tariff harmonization with Europe is undesirable if it is not complemented by a systematic elimination of all forms of NTBs that shield domestic oligopolists from foreign competition at the expense of local customers.

\section{Conclusion}

For both political and economical reasons, TR has met strong resistance to its long held aspiration of hecoming a full member of the European bloc. Despite this, and presumably as a demonstration of commitment to this aspiration, the Turkish authorities have completed the adjustment process as outlined in the 1963 Ankara Agreement, and in 1996 unilaterally undertook a trade reform by harmonizing the country's tariff structure to that of the EU. The resulting Customs Union is regarded as a temporary first step toward full commodity-trade integration within the unified European market.

There are signs, however, that political opposition to the government's pro competitive stance may be strong enough to bloc any further move toward fuller trade liberalization. We have shown in this paper that such a status quo should not be considered 'an acceptable compromise'. According to our evaluations using applied intertemporal GE analysis, the Turkish households would be impoverished by a partial trade reform. In other words, to be welfare improving, the trade reform would have to be pursued further and nontariff barriers on European trade removed. Failure to do so could be more detrimental to domestic welfare than no reform at all.

\section{Acknowledgements}

Mercenier gratefully acknowledges financial support from the FCAR of the Government of Quebec and the SSHRC of the Government of Canada. 


\section{References}

Celasun, M., 1986, A general equilibrium model of the Turkish economy, SIMLOG-1 METU Studies in Development 13, nos. 1-2, 29-64.

Harrison, G., T. Rutherford and D. Tarr, 1993, Trade reform in the partially liberalized economy of Turkey, World Bank Economic Review 7, no. 2, 191-217.

Kose, A. and E. Yeldan, 1996, Turkiye ekonomisinde sektorel isgucu istihdami ve ucret yapisi uzerine bir deneme, iktisat, Isletme ve Finans 11, no. 118, 18-25.

Mercenier, J., 1995a, Can '1992' reduce unemployment in Europe? On welfare and employment effects of Europe's move to a single market, Journal of Policy Modeling 17, no. 1, 1-37.

Mercenier, J., 1995b, Nonuniqueness of solutions in applied general equilibrium models with scale economies and imperfect competition, Economic Theory 6, 161-177.

Mercenier, J. and P. Michel, 1994, Discrete time finite horizon approximation of optimal growth with steady state invariance, Econometrica 62, 635-656.

Mercenier, J. and E. Yeldan, 1996, How prescribed policy can mislead when data are defective: A follow up to Srinivasan (1994) using general equilibrium, Staff report 207 (Research Department, Federal Reserve Bank of Minneapolis, Minneapolis, MN).

Smith, A. and A.J. Venables, 1988, Completing the internal market in the European Community: Some industry simulations, European Economic Review 32, 1501-1525.

Yeldan, E., 1989, Structural adjustment and trade in Turkey: Investigating the alternatives that are beyond export-led growth, Journal of Policy Modeling 11, no. 2, 273-296. 